\title{
Editorial \\ Climate Factors Contribute to Grassland Net Primary Productivity
}

\author{
Goetz M. Richter ${ }^{1, *(D)}$ and Cairistiona F. E. Topp ${ }^{2}$ (D) \\ 1 Rothamsted Research, Sustainable Agriculture Sciences, Harpenden AL5 2JQ, UK \\ 2 SRUC, Peter Wilson Building, West Mains Rd., Edinburgh EH9 3JG, UK; kairsty.topp@sruc.ac.uk \\ * Correspondence: goetz.richter@rothamsted.ac.uk
}

Citation: Richter, G.M.; Topp, C.F.E. Climate Factors Contribute to Grassland Net Primary Productivity. Agronomy 2021, 11, 1076. https:// doi.org/10.3390/agronomy11061076

Received: 6 May 2021

Accepted: 23 May 2021

Published: 26 May 2021

Publisher's Note: MDPI stays neutral with regard to jurisdictional claims in published maps and institutional affiliations.

Copyright: () 2021 by the authors. Licensee MDPI, Basel, Switzerland. This article is an open access article distributed under the terms and conditions of the Creative Commons Attribution (CC BY) license (https:// creativecommons.org/licenses/by/ $4.0 /)$.
Our call set out to enlarge the evidence base and methods for improving and evaluating grasslands in a changing environment as a sustainable ecosystem for all life. We hoped for articles that illustrate the response of grassland systems to changes in pedo-climatic conditions, temperature and water, how management could be optimised, adapted to climatic challenges, and the potential of grassland to improve soil biophysical and geochemical properties. Out of six broad topics, the articles in this Special Issue addressed three: sward development affected by temperature and drought, and modelling effects at the field and landscape scale. Maybe a fourth topic was addressed, considering that one model was implemented as a teaching and exploratory management tool.

Grasslands are important across the world and we received contributions from four continents. These could be roughly divided into three different climatic regions: humid temperate (Chile, Great Britain), semi-arid cold (Mongolia) and warm (South Africa) climates. Interestingly, the objectives for temperate regions were mostly about managing and optimizing (high) productivity, improved grassland. In the semi-arid regions, the paper focused more on the response of natural grasslands to the increasing climatic constraints, fluctuations in temperature and precipitation. The approaches chosen were empirical [1-3] providing evidence for dose-response relationships for management effects and environmental changes. These are essential to derive parameters for process-based modelling as shown by Giannitsopoulos [4], as well as for understanding ecological phenomena and implementing observed changes in functional groups [3] and functional types [5].

Calvache et al. [1,2] provide the evidence for optimising yield and quality as a function of off-take intensity for mixed grazing and mowing systems, comparing an indigenous to the widely used European grass forage species (Lolium p.). Giannitsopoulos and colleagues demonstrate that the expanded LINGRA model can emulate such effects on production and composition once calibrated for high-performance grassland [4]. Experimentalists should feel encouraged to use this type of model for further work to develop and test research hypotheses and for consultancy purposes. Nanzad and his team demonstrate in their study for Mongolia that models are a crucial component in the analysis of groundand space-based evidence [5]. Magandana et al. should follow up their nice experimental results [3] by collaborating with mathematical modellers to raise their analysis to another level, to enable an impact assessment at the sub-continental scale.

The content of this Special Issue should encourage experimentalists to use processbased, functional models; this would be a perfect outcome and step forward, well worth the initial hope and sustained effort. 


\section{References}

1. Calvache, I.; Balocchi, O.; Alonso, M.; Keim, J.P.; López, I.F. Thermal Time as a Parameter to Determine Optimal Defoliation Frequency of Perennial Ryegrass (Lolium perenne L.) and Pasture Brome (Bromus valdivianus Phil.). Agronomy 2020, 10, 620. [CrossRef]

2. Calvache, I.; Balocchi, O.; Arias, R.; Alonso, M. The Use of Thermal Time to Describe and Predict Growth and Nutritive Value of Lolium perenne L. and Bromus valdivianus Phil. Agronomy 2021, 11, 774. [CrossRef]

3. Magandana, T.P.; Hassen, A.; Tesfamariam, E.H. Annual net primary productivity of different functional groups as affected by different intensities of rainfall reduction in the semi-arid grasslands of the Gauteng province in South Africa. Agronomy 2021, 11, 730. [CrossRef]

4. Giannitsopoulos, M.L.; Burgess, P.J.; Richter, G.M.; Bell, M.J.; Topp, C.F.; Ingram, J.; Takahashi, T. Modelling the interactions of soils, climate, and management for grass production in England and Wales. Agronomy 2021, 11, 677. [CrossRef]

5. Nanzad, L.; Zhang, J.; Batdelger, G.; Pangali Sharma, T.P.; Koju, U.A.; Wang, J.; Nabil, M. Analyzing NPP Response of Different Rangeland Types to Climatic Parameters over Mongolia. Agronomy 2021, 11, 647. [CrossRef] 